\title{
Successful Organic Production Practices in the Southern Cone
}

\author{
Cecilia Céspedes-León ${ }^{1}$, Mónica Graciela Balzarini ${ }^{2}$, Roberto José Zoppolo ${ }^{3}$, Hugo Alberto Zarza ${ }^{4}$, Elsa Mirta \\ Margarita Rodríguez ${ }^{5}$, Nélida Isabel Granval ${ }^{6}$, \& Iván Amado Torrico ${ }^{7}$ \\ ${ }^{1}$ Instituto de Investigaciones Agropecuarias, Chile \\ ${ }^{2}$ Universidad Nacional de Córdoba, CONICET, Argentina \\ ${ }^{3}$ Instituto Nacional de Investigación Agropecuaria (Uruguay), Uruguay \\ ${ }^{4}$ Instituto Paraguayo de Tecnología Agropecuaria, Paraguay \\ ${ }^{5}$ Universidad Nacional de Mar del Plata, Argentina \\ ${ }^{6}$ Instituto Nacional de Tecnología Agropecuaria, Argentina \\ ${ }^{7}$ Instituto Nacional de Innovación Agropecuaria y Forestal, Plurinational State of Bolivia \\ Correspondence: Roberto José Zoppolo, Instituto Nacional de Investigación Agropecuaria (Uruguay), Uruguay. \\ E-mail: rzoppolo@inia.org.uy
}

Received: April 3, 2017 Accepted: May 13, 2017 Online Published: June 1, 2017

doi:10.5539/sar.v6n3p26 URL: https://doi.org/10.5539/sar.v6n3p26

\begin{abstract}
The growth of demand of organic products has increased the interest of growers all around the World. To reach a sustainable organic production system, growers have to go through a long and difficult process. Eighty-one successful organic production systems in the Southern Cone of America were evaluated regarding management practices, such as disease control, soil fertility, and biodiversity management. The aim of the study was to determine associations between production techniques, farmer training, experience in organic agriculture, yields obtained, and the contribution of organic production to the profitability of farmers. A multivariate analysis was performed to characterize the variability between systems, correlate the management variables and explain economic sustainability. The economic sustainability of farmers was highly correlated with self-production of fungicides and insecticides, use of permitted commercial fertilizers, organic matter application, the use of natural enemies, commercially permitted fungicides and insecticides and the implementation of preventive practices for disease management. Pest monitoring correlated significantly with farmer training and sustainable practices implementation. Farmer's perception on the importance of crop diversity in organic production correlated with the importance of external inputs independence, green manure, cover crop, and the experience of farmers in organic production. Farmers who implemented more management practices had yield losses below 20\% of total production and a gross margin of organic farming of more than 1.5 times the minimum wage of the country than farmers that implemented few or no management practices.
\end{abstract}

Keywords: sustainable management, preventive practices, biodiversity, soil organic matter, weed control

\section{Introduction}

Sustainable agriculture is an option for integral development that can help consolidate the production of healthy food in highly competitive growing markets. According to the latest survey by FiBL-IFOAM regarding certified organic agriculture worldwide (Willer \& Lernoud, 2016), there was a steady growth of world production of organic crops in the last decade, reaching 43.7 million ha of organic farmland in 2014. In Latin America, more than 387000 producers managed 6.8 million hectares organically in 2014, representing $15.5 \%$ of the global organic production area and $1.1 \%$ of the global agricultural area. In addition, the market for organic products continues to grow, with estimated sales of $\$ 80$ billion USD in 2014 and a 530\% growth since 1999 (IFOAM, 2015). The countries leading in land share under organic production in the region are Argentina (3.06 million ha), Uruguay (1.31 million ha), and Brazil (0.71 million ha) (Willer \& Lernoud, 2016). While exports continue to be the main activity, local markets are beginning to grow and diversify. The most important destinations for organic production from Latin America are Europe, USA, and Japan, making up about $85 \%$ of production in the region (Willer \& Lernoud, 2016).

Organic agriculture is a production system based on respect for the existing relationships in nature. Thus, it 
favors the conservation of natural resources and the environment, contributing to the health of producers and consumers. It thrives for the development of agricultural production systems based on ecological, economic and social equilibrium (Cussianovich, 2001). Organic farming promotes the increase of $\mathrm{C}$ in the soil, through the contributions of organic matter such as compost, manure and guano (Gattinger et al., 2012). Thus, more than 30\% of particulate organic matter in the soil can be increased with the application of animal manure and legumes as green manure (Marriott \& Wander, 2006). Soil organic matter provides much more than the ability to store water and nutrients; it plays a critical role in the formation and stabilization of soil structure, which positively affects drainage and resistance to erosion, promotes a healthy soil ecosystem and stimulates organisms involved in the $\mathrm{C}$ cycle, protecting plants from diseases (Weil \& Magdoff, 2005). Organic production is based on soil management, which optimizes the conditions to stimulate biological activity (Cussianovich, 2001); organic farming includes the implementation of recycling practices, application of organic matter to the soil, and biodiversity improvement, without using chemical products. These characteristics can help farmers no longer depend on the use of external inputs and reduce production costs by allowing, in particular, more sustainable family farming (IFOAM, 2014). In addition, the practices used in organic agriculture are environmentally friendly, as they reduce water and soil pollution and increase soil quality, they improve soil quality and pest control, thereby reducing environmental impacts of conventional farming (Birkhofer et al., 2008).

In 2014, the area of organic agricultural land increased mainly in Asia, Africa, and Europe. Opposed to this, since 2011 a global decrease has taken place in Latin America, with the biggest decrease in Argentina, where over 700000 hectares less were reported (Willer \& Lernoud, 2016). Sustainability of organic agriculture (OA) is not granted automatically, and to reach the desired environmental, economical, and social stability growers have to undergo a long and complicated transformation (Sandhua, Wrattenb, \& Cullenc, 2010; Delate, Cambardella, Chase, \& Turnbull, 2015), and from there on look after all the components of the system. Transition from conventional production is one of the main challenges, with a system that has to achieve biological balances and a grower that is processing and incorporating a lot of new information through an intensive learning process (Gomiero, Pimentel, \& Paoletti, 2011). For the success of OA, it is important to assess not only the technical and technological requirements, but also the educational and training background, relationship between farmers and other links of the chain, and economical implications of OA to farmer's profitability (Salazar, 2014). These factors have influenced OA's development in South America as well as in the rest of the world. The general economical restrain suffered in the last decade in the Southern Cone of America has affected the positive trend of a growing organic sector. Still, efforts are being done to develop public policies in accordance with private and civil society organizations, due to the potential of OA in generating high value products, through a system with high mitigation and adaptation capacity to climate change (Willer \& Lernoud, 2017). Very few studies that focus on success factors of OA in South America have been implemented. This study aims to build knowledge by investigating features involved in the success of organic agriculture, identifying associations between practices used in organic production of horticultural crops by successful producers of the Southern Cone of South America. The paper makes a new contribution throughout the quantification of management variables in a wide range of successful organic producers to a better understanding of the concept of sustainability in the case of organic agriculture.

\section{Materials and Methods}

\subsection{Data}

Data were collected via face to face surveys conducted in a random selected organic agriculture region in each of the five participating countries: Argentina, Bolivia, Chile, Paraguay, and Uruguay. These surveys were carried through by a multidisciplinary team of experts from the National Institute for Agricultural and Forestry Innovation (INIAF), Bolivia, National Institute for Agricultural Technology (INTA), Argentina, Paraguayan Institute of Agricultural Technology (IPTA) of Paraguay, National Agricultural Research Institute (INIA), Uruguay, and Institute of Agricultural Research (INIA), Chile. A total of 81 organic horticultural farmers from these countries were surveyed during the 2009-2010 agricultural season. Sample size was fixed at values close to $5 \%$ of regional farmers who considered that their organic farming activity was successful, since they had maintained organic production for at least three consecutive years and earned income for their livelihood, without the need to return to conventional production. Each survey took a whole day of farmer interview with a guiding questionnaire. All crops in the study were selected according to their regional economic importance within organic agriculture. The crops considered were: wine grapes and onion (Argentina, $n=20$ ), cocoa (Bolivia, $\mathrm{n}=10$ ), wine grapes and blueberries (Chile, $\mathrm{n}=18$ ), mango and tomato (Paraguay, $\mathrm{n}=20$ ), tomato and onion (Uruguay, $\mathrm{n}=13$ ).

Information was collected for each of the 81 organic production systems to detect the presence/absence of 
sustainable production practices such as pest, disease and weed management, soil fertility management, and improved biodiversity of the production system. Information was gathered also on some social and economical aspects as the presence/absence of membership to growers organizations; training in OA in the past 5 years (FT); experience (years) in organic production (YOP); percentage of crop losses (loss below or above 20\%) (YL); proportion of gross margin (obtained from the organic production of the main crop), and the minimum wage in each country. All these data were used to generate a simple economic sustainability index (ES) based on the gross margin calculated by subtracting the direct costs from the gross value of production. The ES is a simple indicator to compare economic returns obtained by farmers (Bockstaller et al. 2008) involving also the minimum wage of the country, which was obtained from the Minimum Wage official website (Salario Mínimo, 2014). The ES index was calculated, in our study, as ES = Gross margin/Minimum Wage.

As a complement to the data obtained, in the 2010-2011 agricultural season we recorded each farmer's perception of a list of 17 variables designed ad-hoc from the survey results of the previous year. This list includes variables which were identified as potential OA success factors because of their correlations with ES. Each farmer assigned an importance value (Scale: 1 unimportant, 2 little important, 3 moderately important, 4 important, 5 very important for OA success) to each of the following variables: farmer involvement in organic production (FI), farmer training (FT), farmer knowledge (FK), sustainable practice implementation (SPI), years of organic production (YOP), external inputs independence (EII), green manure and cover crop establishment (GCE), monitoring for pest control (MPC), pest prevention practices (PPP), disease prevention practices (DPP), weed prevention practices (WPP), pest control success (PCS), disease control success (DCS), weed control success (WCS), harvest success (HS), association or cooperative membership (ACM), number of organic crops (NOC), and economic sustainability (ES).

\subsection{Statistical Analysis}

Associations among presence/absence of organic production practices, farmer training, and experience in organic farming were evaluated. Yield losses, and economic sustainability of the farmer were also included in a multiple correspondence analyses (Johnson \& Wichern, 1998). Farmers' perceptions regarding the success factors expressed as the set of 17 quantitative variables above described (Scale: 1 unimportant, 2 little important, 3 moderately important, 4 important, 5 very important for OA success) were evaluated via a Principal Component Analysis, and the results graphically displayed as a biplot (Balzarini, Bruno, Córdoba, \& Teich, 2015). The relative variable contribution of each management variable to explain ES variability was estimated using CART (Classification and Regression Trees) algorithm (Breiman, 2001). CART is an analytic approach used to assess causes of variation for a response variable. It is named "Regression Tree" when the response to be explained is continuous, such as the ES of the production system. A regression tree can be built by using several variables as predictors which can be correlated. Moreover, in this method, the response variable is not necessarily modeled as a linear function of the predictors; on the contrary, the model is a piecewise constant function. Unlike regression models, CART allows us to work under multi-collinearity and non-linear relationships among variables. During data processing, the whole data (root node) are first split into two subsets based on the predictor variable and the value of that variable (threshold) that optimizes the explanation of the response variable. Each subset (daughter node) is then analyzed independently using the same binary partitioning procedure and recursively until a stop criterion is reached. The result of this recursive binary partitioning is a model whose structure can be displayed as a tree-like graph, with each split in the tree labeled according to the variable and threshold used to define the split. All analyses were performed using the statistical software InfoStat (Di Rienzo et al., 2015).

\section{Results and Discussion}

Successful organic farmers in Argentina, Bolivia, Uruguay, and Chile have a first significant difference with those from Paraguay since the former have their crops certified as organic (Table 1). 
Table 1. Baseline characteristics and certification of successful organic farmers included in the study by country and main organic crop considered for the survey in 2009

\begin{tabular}{|c|c|c|c|c|c|c|}
\hline \multirow[b]{2}{*}{ Country } & \multirow[b]{2}{*}{ Main crop } & \multirow[b]{2}{*}{$\begin{array}{l}\text { Number of } \\
\text { farmers }\end{array}$} & \multicolumn{4}{|c|}{ Baseline characteristics } \\
\hline & & & $\begin{array}{c}\text { Field } \\
\text { area }\end{array}$ & $\begin{array}{l}\text { Main crop } \\
\text { area }\end{array}$ & $\begin{array}{c}\text { Other organic crops in the } \\
\text { field }\end{array}$ & $\begin{array}{c}\text { Certified } \\
\text { farmers }\end{array}$ \\
\hline & & & & $a-$ & & $\%$ \\
\hline Argentina & Onion & 10 & 131.0 & 20.8 & Squash, garlic & 100 \\
\hline Argentina & Grape & 10 & 42.3 & 14.3 & Olive & 100 \\
\hline Bolivia & Cocoa & 10 & 6.0 & 5.3 & Banana, orange & 100 \\
\hline Chile & Blueberry & 10 & 28.7 & 3.5 & Raspberry & 100 \\
\hline Chile & Grape & 8 & 28.5 & 26.1 & Olive & 100 \\
\hline Paraguay & Mango & 8 & 10.4 & 0.6 & Citrus & 0 \\
\hline Paraguay & Tomato & 12 & 4.6 & 0.3 & Pepper, strawberry & 0 \\
\hline Uruguay & Onion & 9 & 11.6 & 1.0 & Tomato, lettuce & 89 \\
\hline Uruguay & Tomato & 4 & 9.3 & 0.2 & Lettuce, onion & 75 \\
\hline
\end{tabular}

The proportion of the area used for the production of the main crop selected for the grower was different among countries. While grape and cocoa producers used much of the land area for these organic items, other farmers only set aside about $15 \%$ or less of the land area to the specific crops for which they were surveyed, giving them a much higher biodiversity. Other organic crops accompanying those selected in the study were squash, garlic, olives, banana, raspberry, citrus, peppers, sweet potatoes, strawberries and lettuce.

It is clear that centering the survey on a limited number of specific crops might generate some restriction on the conclusions. Nonetheless, due to the importance of the crops selected, and to the logic that the grower uses similar criteria independently of the crop, the information generated results in a valuable input for the characterization of the successful systems. Undoubtedly, measurements help us to understand, and future surveys with more coverage will add important information. There is emerging, albeit not definitive, evidence that organic farming can improve farm finances, potentially reduce payouts to some farm financial safety nets, and contribute to rural community vitality following more widespread adoption. The existing evidence suggests a greater research effort in these areas is required, with much depending on the relevance of current research results across a wide range of ecozones and farms. If such applicability across many landscapes is confirmed, we coincide with MacRae, Frick and Martin (2007) that it will be important for policy makers to invest in program and policy modifications to take advantage of such possibilities, promoting the use of specific practices.

The sustainable management practices most widely used by farmers were weed damage prevention (84\%), biodiversity improvement (77\%) and the application of organic matter to the soil (54\%) (Table 2).

Table 2. Average use of organic production techniques (\%) for all growers surveyed of the five countries: Argentina, Bolivia, Chile, Paraguay, and Uruguay and for all crops

\begin{tabular}{lcc}
\hline \multicolumn{1}{c}{ Techniques } & Code & Systems $^{+}(\%)$ \\
\hline Weed prevention practices & WPP & 84 \\
Biodiversity improvement & BIO & 77 \\
Certification & CER & 73 \\
Organic matter application & OMA & 54 \\
Pest prevent practices & PPP & 49 \\
Disease prevention practices & DPP & 49 \\
Farmers training & FT & 48 \\
Commercial fungicides & CF & 41 \\
Pest natural enemies & PNE & 36 \\
Permitted commercial fertilizers & PCF & 35 \\
Self-production of insecticides & SPI & 33 \\
Commercial insecticides & CI & 30 \\
Self-production of fungicides & SPF & 22 \\
\hline
\end{tabular}

${ }^{+}$Total percentage of the studied organic production systems $(n=81)$ that use each practice.

These practices are known to maintain crop yields and reduce the density and growth of weeds in systems 
receiving low external inputs (Liebman \& Davis, 2000). These findings are in concordance with previous studies; Abouziena and Haggaag (2016) reported that weed control is considered the major obstacle for the growers in the organic farming, and successful and sustainable weed management systems are those that employ combinations of techniques rather than relying on one method. Similarly, Auerbach, Rundgren, and Scialabba (2013), confirmed that increasing soil organic matter is vital for sustainable crop production.

The multiple correspondence analysis biplot showed that producers with a gross margin higher than 1.5 times the annual minimum wage for their country, performed the following management practices more often than those farmers with a lower gross margin: self-production of fungicides (SPF), self-production of insecticides (SPI), use of permitted commercial fertilizers (PCF), use of natural pest enemies (PNE), use of commercially permitted fungicides and insecticides (CF and $\mathrm{CI}$ ) and organic matter application (OMA) such as compost, vermicompost and/or manure (Figure 1).

The practices associated with crop losses greater than $20 \%$ and unsustainable economy of organic farmers were: lack of weed prevention practices (WPP), lack of organic matter application (OMA) and lack of pest and disease management (CF, PNE, PCF, SPI, DPP, CI, SPF) (Figure 1).

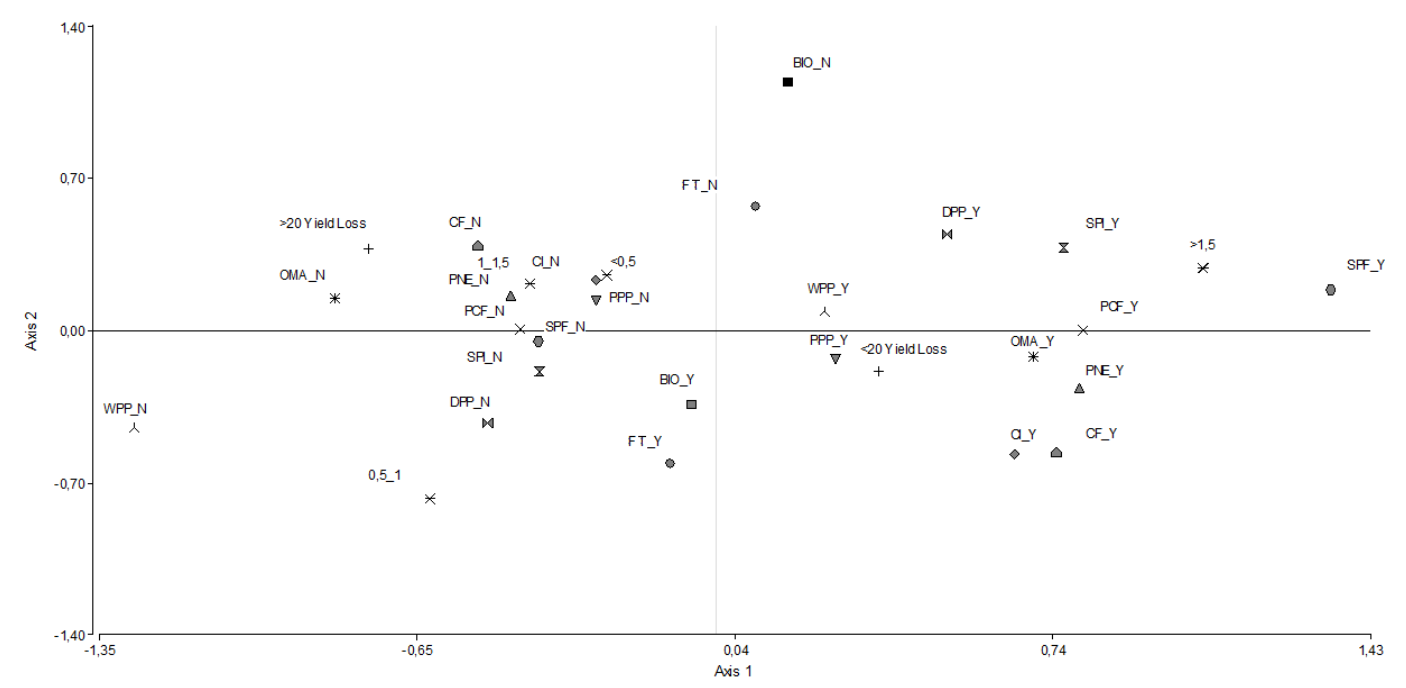

Figure 1. Multiple correspondence biplot analysis. Associations between the following variables that describe organic management practices and economic sustainability

Self-production of fungicides (SPF), self-production of insecticides (SPI), permitted commercial fertilizers (PCF), organic matter application (OMA), pest natural enemies (PNE), commercial fungicides (CF), commercial insecticides (CI), disease prevention practices (DPP), pest prevention practices (PPP), weed prevention practices (WPP), farmer training (FT), biodiversity improvement (BIO), yield loss and economic sustainability (ES). The last letter( $\mathrm{Y}$ or $\mathrm{N})$ in the category names indicates presence/absence.

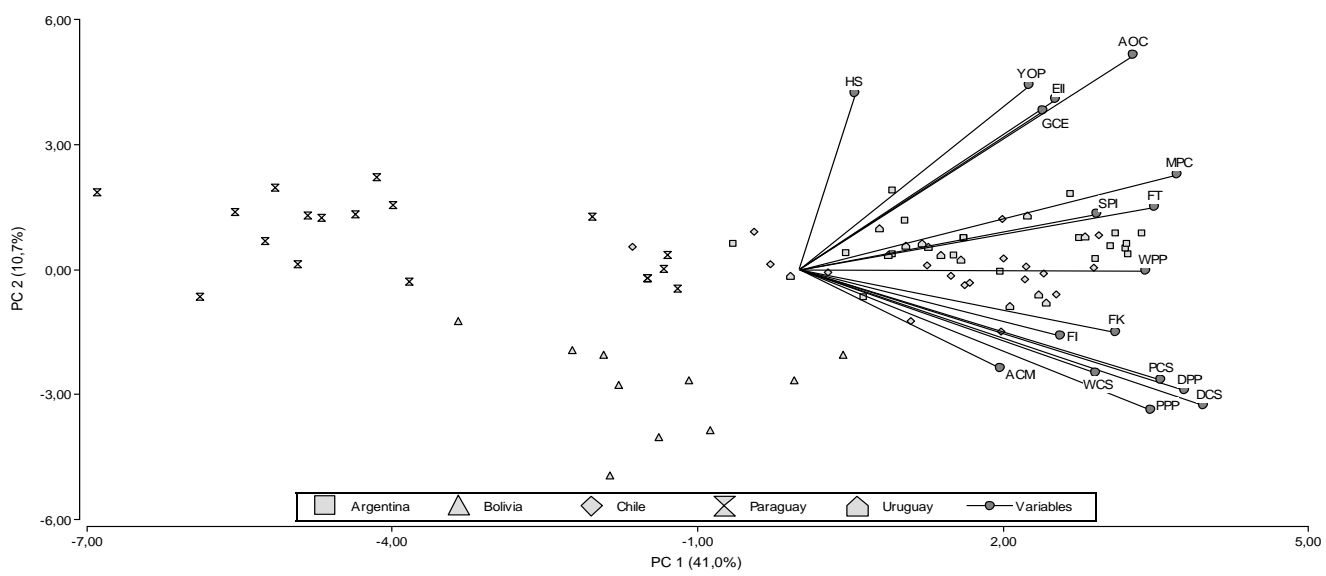

Figure 2. Biplot of the principal components analysis. Scatterplot of farmers $(n=81)$ in the PC1 and PC2 factorial plane 
The biplot shows $51.7 \%$ of the total variability in farmers' perceptions regarding the following variables: harvest success (HS), year in organic production (YOP), external inputs independence (EII), green manure and cover crop establishment (GCE), number of organic crops (NOC), monitoring for pest control (MPC), sustainable practices implementation (SPI), farmer training (FT), weed prevention practices (WPP), farmer knowledge (FK), farmer involvement (FI), pest control success (PCS), disease prevention practices (DPP), diseases control success (DCS), weed control success (WCS), pest prevention practices (PPP), association or cooperative membership (ACM).

Figure 2 shows the biplot of a principal component analysis of the 17 variables identified from the first survey as potential indicators of success in OA. The existence of variability in farmers' perception is observed, even among these successful ones. The scattered points in the chart represent the farmers and the vectors radiating from the origin represent the variables analyzed. The vectors that have a greater projection on the first principal component (PC1), either to the right or left of the axis, indicate the variables with higher contribution in explaining the total variability among farmers. On the PC1 axis, $41 \%$ of the variability in the perceptions among farmers is projected. Growers from Paraguay and Bolivia are separated from growers of Argentina, Chile, and Uruguay in the chart, with the grouping of the latter farmers showing similar perceptions of the list of variables.

Regarding the variables, the following three main groups of correlations were observed. First, farmers' perception regarding the importance of the number of organic crops (NOC) is correlated with the importance given to the external inputs independence (EII) $(r=0.5, \mathrm{P}<0.0001)$, establishment of green manures and cover crops (GCE) $(\mathrm{r}=0.51, \mathrm{P}<0.0001)$ and greater experience of farmers in organic production (YOP) $(\mathrm{r}=0.53, \mathrm{P}<$ 0.0001). Second, correlations were observed between implementing sustainable practices (SPI), farmer training $(\mathrm{FT})(\mathrm{r}=0.47, \mathrm{P}<0.0001)$, monitoring for pest control (MPC) $(\mathrm{r}=0.54, \mathrm{P}<0.0001)$ and preventive practices for weed management (WPP) $(r=0.3, P=0.0072)$. Finally, disease control success (DCS) correlates with: preventive disease management practices (DPP) $(r=0.74, \mathrm{P}<0.0001)$, preventive pest practices (PPP) $(\mathrm{r}=0.67$, $\mathrm{P}<0.0001)$, pest control success (PCS) $(\mathrm{r}=0.73, \mathrm{P}<0.0001)$, weed control success (WCS) $(\mathrm{r}=0.52, \mathrm{P}<$ $0.0001)$, participation of farmers in the production system $(\mathrm{FI})(\mathrm{r}=0.5, \mathrm{P}<0.0001)$, knowledge of farmers about organic production $(\mathrm{FK})(\mathrm{r}=0.6, \mathrm{P}<0.0001)$, and the participation of farmers in associations or cooperatives $(\mathrm{ACM})(\mathrm{r}=0.44, \mathrm{P}<0.0001)$.

The average farmers' perception of the importance of variables selected as potential success factors in organic production is shown in Table 3 for each crop in each studied country.

Table 3. Farmers' perception of the importance of success factors in organic production, by country and main crop

\begin{tabular}{|c|c|c|c|c|c|c|c|c|c|c|c|c|c|c|c|c|c|c|}
\hline & & FI & $\mathrm{T}$ & K & PI & & III & GCE & PPP & & DPP & & $S$ & & & HS & & \\
\hline & & & (6) & (1) & & 0) & ) & (6) & (0) & & ) & & & & & & & \\
\hline Argentina & Grape & & & & & & & & (6) & & & & & & & & & \\
\hline Bolivia & Cocoa & & & & & & & & & & & & & & & & & \\
\hline Chile & & & & & & & & & & & & & & & & & & \\
\hline Chit & & & & & & & & & & & & & & & & & & $\begin{array}{l}3.4 \\
(31)\end{array}$ \\
\hline & & & & & & & & & & & 2.3 & & & & & & & $\begin{array}{l}2.1 \\
(17)\end{array}$ \\
\hline Paraguay & & & 3.8 & $\begin{array}{l}3.8 \\
(12)\end{array}$ & & 4.3 & $\begin{array}{l}2.4 \\
(28)\end{array}$ & $\begin{array}{l}3.6 \\
\text { (19) }\end{array}$ & $\begin{array}{l}4.1 \\
(30)\end{array}$ & t & $\begin{array}{l}3.3 \\
(27)\end{array}$ & & & & & .4 & & $\begin{array}{l}2.8 \\
(16)\end{array}$ \\
\hline Uruguay & Onion & & 4.8 & 4.9 & $\begin{array}{l}4.6 \\
(12)\end{array}$ & 4.1 & $\begin{array}{l}4.0 \\
(22)\end{array}$ & $\begin{array}{l}4.8 \\
(9)\end{array}$ & $\begin{array}{l}4.6 \\
(22)\end{array}$ & 20 & $\begin{array}{l}4.4 \\
(12)\end{array}$ & 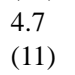 & 4.6 & $\begin{array}{l}4.8 \\
(9)\end{array}$ & & 2.4 & & $\begin{array}{l}4.3 \\
(12)\end{array}$ \\
\hline defuay & $\mathrm{T}$ & $\begin{array}{l}5 . \\
(0\end{array}$ & 4.5 & 3.8 & 4.5 & 4.3 & $\begin{array}{l}4.0 \\
(29)\end{array}$ & 4.5 & $\begin{array}{l}4.5 \\
(13)\end{array}$ & 3.8 & $\begin{array}{l}4.5 \\
\text { (13) }\end{array}$ & 4.8 & 4.5 & 4.5 & 4.8 & 2.5 & & $\begin{array}{l}4.5 \\
(13)\end{array}$ \\
\hline Il countri & & & 4.3 & 4.1 & 4.3 & 4.0 & 3.5 & 4.2 & 4.4 & 3.6 & 4.3 & 4.2 & 4.3 & 4.2 & 4.1 & 2.1 & 4.0 & 3.5 \\
\hline
\end{tabular}

Mean values. Category scale: $1=$ unimportant, $2=$ little important, $3=$ moderately important, $4=$ important, $5=$ very important; $\mathrm{n}=81$ producers. Coefficient of variation (in parentheses).

Factors: FI = farmer involvement, $\mathrm{FT}=$ farmer training, $\mathrm{FK}=$ farmer knowledge, SPI $=$ sustainable practices implementation, $\mathrm{YOP}=$ year in organic production, $\mathrm{EII}=$ external inputs independence, $\mathrm{GCE}=$ green manure and cover crop establishment, $\mathrm{PPP}=$ pest prevention practices, $\mathrm{MPC}=$ monitoring for pest control, $\mathrm{DPP}=$ disease prevention practices, $\mathrm{WPP}=$ weed prevention practices, $\mathrm{PCS}=$ pest control success, $\mathrm{DCS}$ $=$ diseases control success, $\mathrm{WCS}=$ weed control success, $\mathrm{HS}=$ harvest success, $\mathrm{ACM}=$ association or cooperative membership, NOC $=$ number of organic crops. 
The involvement of farmers (FI) in production was the highest weighting factor in the perception of farmers as an indicator of OA success. The coefficients of variation of the different groups of producers show that there is low agreement in perception between Argentine farmers, for both crops, and between grape producers in Chile, regarding the importance of harvest success (HS). The same applies to cocoa farmers in Bolivia, who did not show agreement with the importance of experience in organic production (YOP), independence of external inputs (EII), or the need of monitoring for pest control (MPC). This difference of perception between groups could be explained by the specifics of the main crop being analyzed, its technical challenges in the production process and even in its commercialization system.

The relative contribution of different techniques applied by farmers to the economic sustainability (ES) of the production system is presented in Figure 3.

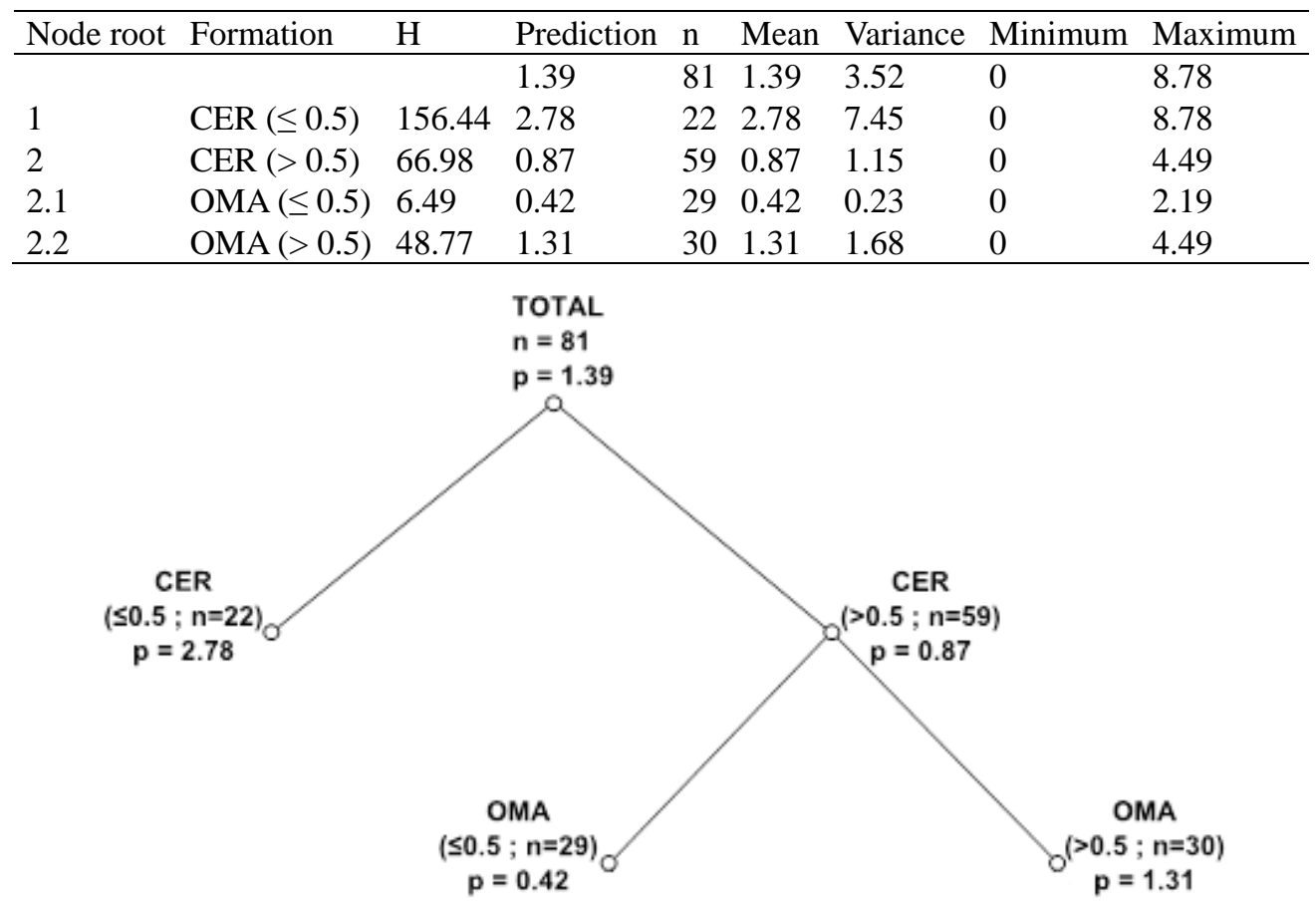

Figure 3. Classification-regression tree: Organic certification (CER), organic matter application (OMA). Techniques applied by organic farmers that best explained economic sustainability (ES) of the production system across countries from the Latin American South Cone (81 successful farmers). Total management data were first split into two subsets based on the predictor variable (CER, organic certification) and its threshold: not certified $(\leq 0.5)$ and certified $(>0.5)$. Each subset, or node, was then analyzed independently using the same procedure.

Second variable explaining ES was organic matter application (OMA, threshold: not uses $(\leq 0.5)$ and uses $(>0.5)$.).Variables making top nodes are the most important to explain ES. Average ES for each node are reported, as Prediction, in the embedded table.

The best explanatory variable for sustainability was certification (CER), but certification is costly and has a negative effect on the economic sustainability (ES) of producers in the Southern Cone involved in this study. These results agree with those reported by Nelson et al. (2010), who indicated that certification is unaffordable to small scale or low-income producers, since it is an expensive process in which the lack of harmonized standards increases certification costs even more. Producers willing to sell in different markets must get their crops certified in several agencies. In this study, producers from Uruguay and Paraguay that were not certified obtained the highest profits $(\mathrm{ES}=2.78$ times the minimum wage), whereas those that had their products certified as organic had an $\mathrm{ES}=0.87$ times the minimum wage, on average. The management variable that increased this average was the organic matter application (OMA), with a marginal effect given by gross margin of $1.31 \mathrm{vs.} 0.42$ times the minimum wage, depending on whether or not organic matter was applied.

\section{Conclusion}

The most frequently implemented management practices by successful farmers in the Southern Cone were weed prevention, biodiversity improvement and the application of organic matter to the soil. The economic 
sustainability of the farmers in the region was more closely correlated to self-production of fungicides and insecticides, use of permitted commercial fertilizers and application of organic matter to the soil. By contrast, the costs of certification of organic production had a negative effect on economic sustainability. Successful farmers in the Southern Cone perceived the level of farmer involvement as an indicator of organic production success. The perception of success in disease control, the importance of monitoring pest control and the importance of increasing the amount of organic crops in farm production were three significant variables in the perceptions of producers who participated in this study, with producers in Argentina, Chile, and Uruguay having different perceptions from producers of Bolivia and Paraguay. Farmers who implemented more management practices had yield losses below $20 \%$ of total production and had a gross margin of organic farming equivalent to more than 1.5 times the minimum wage of that country reaching higher income than farmers that implemented few or no management practices.

\section{Acknowledgements}

We are grateful to all those who participated in the project implementation, contributing to this publication. We are sincerely thankful to the Regional Fund for Agricultural Technology (FONTAGRO), the Cooperative Program for Agrifood and Agroindustrial Technology Development in the Southern Cone (PROCISUR) and the Inter-American Institute for Cooperation on Agriculture (IICA) for their financial support.

\section{References}

Abouziena, H. F., \& Haggag, W. M. (2016). Weed Control in Clean Agriculture: A Review1. Planta daninha, Viçosa, 34(2), 377-392. https://doi.org/10.1590/S0100-83582016340200019

Auerbach, R., Rundgren, G., \& Scialabba, N. (Ed.) (2013). Organic agriculture: African experiences in resilience and sustainability. Food and Agriculture Organization of the United Nations, Rome. p. 200. http://www.fao.org/docrep/018/i3294e/i3294e.pdf

Balzarini, M., Bruno, C., Córdoba, M., \& Teich, I. (2015). Herramientas en el Análisis Estadístico Multivariado. Ed. Brujas. Córdoba, Argentina.

Birkhofer, K., Bezemer, T. M., Bloem, J., Bonkowski, M., Christensen, S., Dubois, D., ... Mäder, P. (2008). Long-term organic farming fosters below and aboveground biota: Implications for soil quality, biological control and productivity. Soil Biology and Biochemistry, 40(9), 2297-2308. https://doi.org/10.1016/j.soilbio.2008.05.007

Bockstaller, C., Guichard, L., Makowski, D., Aveline, A., Girardin, P., \& Plantureux, S. (2008). Agri-environmental indicators to assess cropping and farming systems. A review. Agronomy for Sustainable Development, Springer Verlag/EDP Sciences/INRA. 28(1), 139-149. https://doi.org/10.1051/agro:2007052

Breiman, L. (2001). Random forests. Mach. Learn, 45(1), 5-32. https://doi.org/10.1023/A:1010933404324

Cussianovich, P. (2001). Una aproximación a la agricultura orgánica. Revista Agricultura Orgánica 1:1-7. Available at: http://repiica.iica.int/docs/B1865e/B1865e.pdf

Delate, K., Cambardella, C., Chase, C., \& Turnbull, R. (2015). A Review of Long-Term Organic Comparison Trials in the U.S., Sustainable Agriculture Research, 4(3), 5-14. https://doi.org/10.5539/sar.v4n3p5

Di Rienzo, J. A., Casanoves, F., Balzarini, M. G., Gonzalez, L., Tablada, M., \& Robledo, C. W. (2015). InfoStat versión 2015. Grupo InfoStat, Universidad Nacional de Córdoba, Facultad de Ciencias Agropecuarias, Córdoba, Argentina. Available at http://www.infostat.com.ar

Gattinger, A., Muller, A., Haeni, M., Sikinner, C., Fliessbach, A., \& Buchmann, N. (2012). Enhanced top soil carbon stocks under organic farming. Proceedings of the National Academy of Sciences of the United States of America, 109, 18226-18231. https://doi.org/10.1073/pnas.1209429109

Gomiero, T., Pimentel, D., \& Paoletti, M. (2011). Environmental Impact of Different Agricultural Management Practices: Conventional vs. Organic Agriculture. Journal Critical Reviews in Plant Sciences, 30(1-2), Towards a More Sustainable Agriculture, 95-124.

IFOAM. (2014). La producción orgánica para la agricultura familiar campesina. 2014. Año internacional de la agricultura familiar. International Federation of Organic Agriculture Movements (IFOAM) Bonn, Alemania. Available at www.ifoam.org/sites/default/files/ifoam_iyff_flyer_es_ses_web_0.pdf (accessed 28 November 2014).

IFOAM. (2015). Into the future. Consolidated annual report of IFOAM Organics International. Available at http://www.ifoam.bio/sites/default/files/annual_report_2015_0.pdf (accesed 19 of March 2017). 
Johnson R., \& Wichern, D. (2008). Applied Multivariate Statistical Analysis, 6th Edition. Pearson. ISBN: 978-0131877153

Liebman, M., \& Davis, A. (2000). Integration of soil, crop and weed management in low-external-input farming systems. Weed Research, 40, 27-47. https://doi.org/10.1046/j.1365-3180.2000.00164.x

MacRae, R. J., Frick, B., \& Martin, R. C. (2007). Economic and social impacts of organic production systems. Canadian Journal of Plant Science, 87(5), 1037-1044. https://doi.org/10.4141/CJPS07135

Marriott, E., \& Wander, M. (2006). Total and labile soil organic matter in organic and conventional farming systems. Soil Science Society of America Journal, 70, 950-959. https://doi.org/10.2136/sssaj2005.0241

Nelson, E., Gómez, L., Schwentesius, R., \& Gómez, M. (2010). Participatory organic certification in Mexico: an alternative approach to maintaining the integrity of the organic label. Agriculture and Human, 27, 227-237. https://doi.org/10.1007/s10460-009-9205-x

SALARIO MINIMO 2014 (2014). - Powered by WordPress - Theme RedBel by Belouga. In: http://www.salariominimoen.com/latinoamerica-salario-minimo (Accessed 20 June 2014).

Salazar, R. (2014). Going Organic in the Philippines: Social and Institutional Features. Agroecology and Sustainable Food Systems, 38, 199-229. https://doi.org/10.1080/21683565.2013.833155

Sandhua, H., Wrattenb, S., \& Cullenc, R. (2010). Review: Organic agriculture and ecosystem services. Environmental Science \& Policy, 13(1), 1-7. https://doi.org/10.1016/j.envsci.2009.11.002

Weil, R., \& Magdoff, F. (2005). Significance of soil organic matter to soil quality and health. In Magdoff, F., and R.R. Weil (eds.) Soil organic matter in sustainable agriculture. CRC Press, Boca Raton, Florida, USA.

Willer, H., \& Lernoud, J. (Eds.) (2017). The world of organic agriculture. Statistics and emerging trends 2016. Research Institute of Organic Agriculture (FIBL), Frick, and International Federation of Organic Agriculture Movements (IFOAM), Bonn, Germany.

http://www.fedeorganicos.com/wp-content/uploads/2017/03/3503-organic-world-2017.pdf (Accessed 10 January 2017).

\section{Copyrights}

Copyright for this article is retained by the author(s), with first publication rights granted to the journal.

This is an open-access article distributed under the terms and conditions of the Creative Commons Attribution license (http://creativecommons.org/licenses/by/3.0/). 